\title{
Hair growth promoting effect of toothpaste in C57BL/6 mice: Active components and their effects on genomic expression
}

\author{
Seunghyun Ahn ${ }^{1}$ (D) $\cdot$ Jung Yeon Lee ${ }^{1}$ (i) $\cdot$ Yujeong Shin ${ }^{1}$ (D) $\cdot$ Jinkyung Lee $^{2}$ (D) \\ Seol-Hoon Lee ${ }^{1}$ (D) $\cdot$ Seyeon Park ${ }^{1}$ (I)

\section{C57BL/6 마우스에서 치약의 모발성장 촉진 효과: 유효 성분과 유전체 발현에 미치는 영향}

안숭현 ${ }^{1}$ - 이정 연 ${ }^{1}$ - 신유정 ${ }^{1}$ - 이진경 ${ }^{2}$ - 이설훈 ${ }^{1} \cdot$ 박세 연 $^{1}$

Received: 13 October 2021 / Accepted: 15 November 2021 / Published Online: 31 December 2021

(C) The Korean Society for Applied Biological Chemistry 2021

\begin{abstract}
It has been suggested that some toothpastes have the potential to promote hair growth. However, there was no scientific verification on the hair growth effect of toothpaste and no scientific report on major active ingredients in toothpaste. In this work, toothpaste and its constituents were applied topically over the shaved skin of C57BL/6 mice and evaluated. Results indicated that toothpaste showed hair growth effect. Also, the effect of toothpaste constituents on the proliferation rate of keratinocyte cells was investigated. The mixture solution of $\alpha$-tocopherol acetate, l-menthol, and stevioside, each of that was known to promote hair growth and other toothpaste constituents were applied topically on mouse skin. When the mixture solution was included, hair growth effect was observed in mice. Transcriptome analysis was performed using the dorsal epidermis of mice from the group treated with toothpaste, the mixture which are presumed to be active ingredients for hair growth, and from mice used for
\end{abstract}

Seyeon Park $(\bowtie)$

E-mail: sypark21@dongduk.ac.kr

${ }^{1}$ Department of Applied chemistry and Cosmetics, Dongduk Women's University, Seoul 02748, Republic of Korea

${ }^{2}$ Department of Health and Cosmetics, Dongduk Women's University, Seoul 02748, Republic of Korea

This is an Open Access article distributed under the terms of the Creative Commons Attribution Non-Commercial License (http://creativecommons. org/licenses/by-nc/3.0/) which permits unrestricted non-commercial use, distribution, and reproduction in any medium, provided the original work is properly cited. the control group. As a result of analyzing the genes whose expression was significantly changed in each treatment group, the gene patterns of the two groups were very similar. Also, when functional genomic analysis was performed, genes with functions related to hair growth regulation showed a high extent of the change in both groups. Hair growth-related genes whose expression was changed in both groups included keratin, keratinrelated proteins, forkhead box, and sonic hedgehog. Therefore, the hair growth effect of toothpaste is thought to be due to the effect of a mixture of $\alpha$-tocopherol acetate, l-menthol, and stevioside.

Keywords $\alpha$-tocopherol acetate $\cdot \mathrm{C} 57 \mathrm{BL} / 6 \cdot$ Hair regrowth · L-menthol · Stevioside

\section{서 론}

현재까지 탈모치료제로서 US FDA 승인을 받은 것은 구강 투 여 하는 finasteride (Proscar $^{\mathbb{R}}$, Merck, Darmstadt, Germany)와 국소적으로 바르는 minoxidil (Rogaine ${ }^{\circledR}$, Johnson \& Johnson, New Brunswick, NJ, USA)이 있다[1]. 전통적으로 사용되어진 식물 유래 성분들은 탈모 치료제의 대체 방안으로 여러 세기 동안 사용되어 왔지만 과학적인 근거를 바탕으로 평가된 것은 소수에 불과하다. 또한 이들에 포함된 단일 성분에 대한 발모 효능 및 메커니즘이 알려져 있는 경우도 많지 않은 실정이다. 치약은 두피 세정제로 사용하였을 때 발모 효과가 나타났다는 민간요법이 전해져 왔으나, 아직까지 효과가 검증된 경우는 부 
족하여 이에 대한 연구가 필요한 실정이다. 산화스트레스 (Oxidative stress)는 원형탈모(Alopecia Areata)를 일으키는 하나 의 원인으로 연구되고 있으며 치약의 성분 중 항산화 효과를 보이는 tocopherol을 이용하여 원형탈모에 대한 임상시험을 진 행한 결과 tocotrienol(토코트라이에놀)을 공급한 지원자군이 placebo약물을 공급한 지원자 군과 비교하여 유의미한 모발 성 장을 나타나낸 것으로 보고되었다[2]. 이는 두피의 산화스트레 스가 tocotrienol에 의한 항산화 활성에 의해 감소되었기 때문일 것으로 제시되었다[2]. 그러나 tocopherol을 국소적으로 바르는 방법으로 적용한 동물 모델 실험이나 임상적으로 평가한 실험 에 대해서는 아직까지 보고된 바가 없다. 또한 치약의 한 성분 인 1-menthol을 이용하여 모발성장에 미치는 영향에 대해서 본 연구에 의하면 menthol을 포함하고 있는 페퍼민트 오일 (Peppermint oil)을 C57BL/6 마우스 피부에 4주간 국소적으로 적용한 경우 이들의 진피층(Dermis)이 두꺼워지고, 여포(Follicle) 수가 증가하고 깊이가 깊어지는 것을 유도하여 모발성장 효과 를 나타낸다고 제안하였다[3]. 뿐만 아니라 stevioside를 포함하 고 있는 stevia extract (스테비아 추출물)을 구강투여하거나 국 소부위에 발랐을 때 포유류의 모발 혹은 털이 강화된다는 것이 보고된 바 있다[4]. 본 연구는 치약을 구성하는 성분( $\alpha$-tocopherol acetate (토코페롤 아세테이트), 1-menthol (멘솔), Stevioside (스 테비오사이드)가 각질세포주인 $\mathrm{HaCaT}$ 세포의 성장촉진에 미치 는 영향을 평가하였다. 또한 $\mathrm{C} 57 \mathrm{BL} / 6$ 마우스들의 제모 된 등 쪽 피부에 위의 세가지 성분의 혼합액을 국소적으로 적용하여 모발의 성장 촉진 여부를 평가하여 이들이 발모에 미치는 영향 에 대해 알아보고자 하였다.

\section{재료 및 방법}

\section{세포배양과 세포증식 측정}

사람의 각질(Keratinocyte) 세포주인 $\mathrm{HaCaT}$ 세포는 Korean Cell Line Bank (Seoul, Korea)에서 구입하였고 10\% fetal bovine serum과 penicillin-streptomycin이 첨가된 Dulbecco modified Eagle medium (Gibco, Carlsbad, CA, USA) 배지를 사용하여 $37{ }^{\circ} \mathrm{C}, 5 \% \quad \mathrm{CO}_{2}$ 조건의 인큐베이터에서 배양하였다. 1차 배양된 사람모낭의 모유두세포는 Cell Engineering for Origin (Seoul, Korea)에서 구입하였고 human hair follicle dermal papilla cells growth medium $\left(\mathrm{CEFOgro}^{\mathrm{TM}} \mathrm{HDP}\right.$, Cell engineering for origin)배지를 사용하여 $37^{\circ} \mathrm{C}, 5 \% \mathrm{CO}_{2}$ 조건의 인큐베이터에서 세포배양 하였다. 세포 증식을 측정하기 위해 [3-(4,5-dimethylthiazol-2-yl)-5-(3-carboxymethoxyphenyl)-2-(4sulfophenyl)-2H-tetrazolium, inner salt] (MTS) assay kit (Promega, Madison, WI, USA)를 사용하였다. 세포를 96well plate에 $1.5 \times 10^{4}$ 개씩 분주하고 $\alpha$-tocopherol acetate, 1-menthol, stevioside 와 minoxidil을 각각 $0,0.2,1,5,10,50 \mu \mathrm{M}$ 농도로 24시간, 48시간 동안 독립적으로 세번씩 반복하여 처리하였다. MTS 용 액을 well당 $20 \mu \mathrm{L}$ 씩 넣고 1 시간 동안 $37^{\circ} \mathrm{C}, 5 \% \mathrm{CO}_{2}$ 조건에 서 배양하였다. 이후 ELISA reader기(Bio-Tek, Winooski, VT, $\mathrm{USA}$ )를 사용하여 $490 \mathrm{~nm}$ 에서의 흡광도를 측정하였다.

\section{동물에서의 발모 조사}

모든 동물실험은 동덕여자대학교 동물 윤리 위원회의 승인하에 이루어졌다(No201803-04). 5주된 수컷 C57BL/6 쥐(18-20 g)를 대한바이오링크(Incheon, Korea)에서 구입하였으며 12:12시간 명 암주기로 온도 $\left(25 \pm 3{ }^{\circ} \mathrm{C}\right)$ 의 실험실에서 7 일간 적응기에 두었다. 첫 번째 실험에서 $\mathrm{C} 57 \mathrm{BL} / 6$ 쥐를 5마리씩 5그룹으로 나누었다. 치약을 구성하는 물질 중 발모에 효과를 나타내는 활성물질을 찾기 위해 추가 실험을 진행하였다. $\mathrm{C} 57 \mathrm{BL} / 6$ 쥐를 5마리씩 6 그룹으로 나누었고 각 그룹에 처리된 약물은 다음과 같다; $\mathrm{A}$ 그룹: vehicle, $\mathrm{B}$ 그룹: minoxidil $3 \%, \mathrm{C}$ 그룹: $\mathrm{Na}_{2} \mathrm{FPO}_{3}$ $0.76 \%$, Calcium glycerol phosphate $0.13 \%, \mathrm{NaCl} 5 \%$, pyridoxine hydrochloride $0.03 \%$, allantoin $0.5 \%$, tranexanmic acid $0.05 \%$, aminocaproic acid $0.05 \%$, sodium pyrophosphate $2 \%, \mathrm{CaCO}_{3}$ $5 \%, \mathrm{Ca}_{3}\left(\mathrm{PO}_{4}\right)_{2} 3.2 \%$, silica gel $2 \%$ 로 구성된 치약성분 혼합 물, $\mathrm{D}$ 그룹: $\mathrm{C}$ 그룹 혼합물에 1-menthol $0.2 \%, \alpha$-tocopherol acetate $0.5 \%$, stevioside $0.1 \%$ 를 첨가시킨 혼합물, $\mathrm{F}$ 그룹: 치 약 $20 \%$. 각 그룹에 해당되는 약물을 등쪽 털을 제모한 쥐에 매 일 8주 동안 도포하여 발모 효과를 평가하였다. 치약은 phosphate buffered saline (PBS)로 희석하였으며 도포 후 PBS 로 등을 세척해주었다. 휴지기(Telogen)-성장기(Anagen) 전환을 나타내는 피부색을 관찰하고, 매주 사진을 기록하였다. 전체 제 모된 면적 중에서 발모된 면적의 비율을 평가하여 발모 정도를 평가하였다[5]. 8주 뒤 쥐를 안락사 시키고, 샘플을 도포한 등 의 중앙 부분 조직을 잘라내어, Trizol (Invitrogen, Carlsbad, $\mathrm{CA}, \mathrm{USA}$ )에 넣고 $\mathrm{RNA}$ 를 추출하였다.

\section{통계처리}

그래프의 결과들은 세번 또는 다섯번 측정값의 평균 \pm 표준편차 값으로 표시되었다. 통계적 유의성은 Sigma Plot 프로그램에서 Student's t-test를 이용하여 결정하였다.

\section{RNA 추출}

유전자 발현 양상 분석을 위한 $\mathrm{RNA}$ 를 얻기 위해 피부 조직 조각을 용해시켰다. 총 RNA는 RNeasy Mini Kit (Qiagen, Hilden, Germany)의 프로토콜에 따라 분리되었다. 분리된 RNA 의 순도와 무결성은 RNA 6000 Nano-chip을 사용한 Agilent 2100 Bioanalyzer를 통해 분석되었다(Agilent Technologies, Böblingen, Germany). 각 대조군과 처리군의 총 RNA은 전사체 의 프로파일링에 사용되었다. Library는 Lexogen (Vienna, Austria)의 Quant-Seq 3'mRNA-Seq library prep kit에 의해 구 축되었다. 시퀀싱 플랫폼으로 NextSeq 500 (Illumina, San Diego, CA, USA)이 사용되었으며 library layout은 Illumina $\mathrm{SE75}$ 이 사용되었다.

\section{전사체 분석}

QuentSeq3'mRNA-Seq 전사체 분석은 이바이오젠(ebiogen Inc, Seoul, Korea)에서 수행하였다. Bewtie2를 이용하여 시퀀스를 정 렬하였고[6] 정렬 파일은 전사체를 조립하고, 그 양을 추정하며 유전자의 차등 발현을 검출 하는데 사용 되었다. 차별적으로 발 현된 유전자는 Bedtools의 적용 범위를 사용하여 고유 및 다중 
정렬의 수를 기반으로 결정되었다[7]. Read count data는 Bioconductor를 사용하여 R 내에서 EdgeR을 사용하는 분위수 정규화 방법에 따라 처리되었다[8]. 유전자 분류는 DAVID (http://david.abcc.ncifcrf.gov/) 및 Medline 데이터베이스(http:// www.ncbi.nlm.nih.gov/)에서 검색한 결과를 기반으로 하였다. 발 모효과를 보인 쥐의 조직에서 변화를 보인 관련 유전자들의 상 관 관계를 분석하기 위하여http://string-db.org/에서 multiple protein의 network를 분석하였다.

\section{결과와 고찰}

\section{C57BL/6 마우스에서 치약의 발모 효과}

Fig. 1에서 나타낸 것과 같이, 국소 부위에 10,20 그리고 $50 \%$ 의 치약을 도포한 경우 C57BL/6 마우스에서 유의미한 발모촉 진이 나타났다. 각 군의 마우스들은 등 부위가 도포 직후부터 회색 부위(Grey spot)로 변화하는 시점을 기록하였다. 20와 $50 \%$ 치약을 도포한 그룹에서 도포 직후 분홍피부가 회색으로

(A) A

B

C

D

$\mathrm{E}$

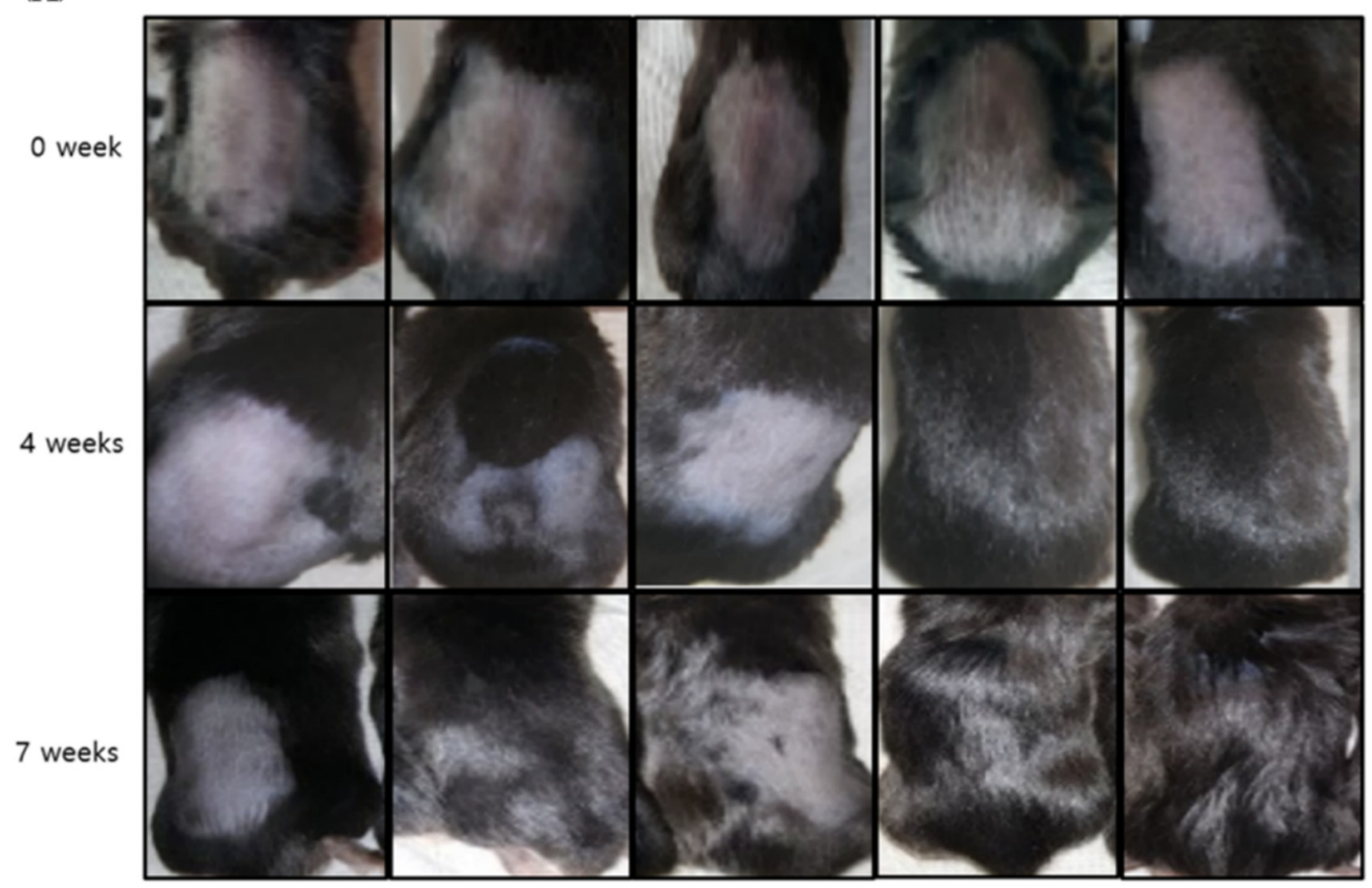

(B)

Growth Area \%

$\square 4$ weeks $\square 8$ weeks

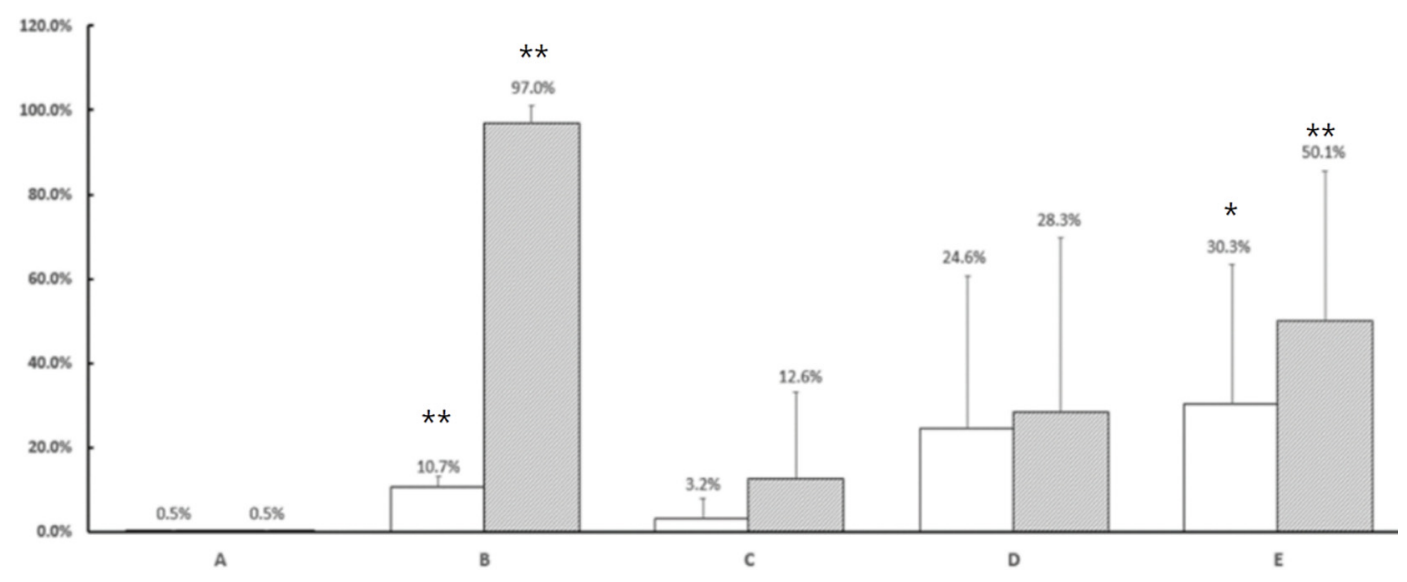

Fig. 1 Effects of topical application of toothpaste on hair growth induction in C57BL/6 mice. (A) Mice were divided into 5 groups: A: CTR (vehicle), B: $3 \%$ minoxidil, C: $10 \%$ toothpaste(TP), D: $20 \%$ TP, and E: 50\% TP. Time scale of hair regrowth in C57BL/6 mice during 7 weeks post-shaving. The skin on the back of each mouse was photographed every week. (B) Quantitative comparison of hair growth. The hair growth area was scanned and the area was calculated using ImageJ program. The value is represented as the percentage of the hair growth area relative to the shaved area. The average value is shown, with error bar indicating standard deviation. The calculations excluded the highest and lowest values in each group. Statistical analyses were performed in comparison with the vehicle-treated control group $\left({ }^{*} p<0.05 ; *^{*} p<0.01 ; \mathrm{n}=3\right)$ 
변한 시기는 13 일 이후부터 관찰되었으며 이는 27 일이 소요된 대조군과 21 일이 걸린 $3 \%$ 의 minoxidil을 도포한 그룹보다 빠 른 것으로 나타났다. 털이 자란 정도를 정량적으로 비교하기 위 해 털이 난 부위의 면적을 사진으로 찍고 이미지화하여 ImageJ 프로그램을 이용하여 계산하였다. Fig. 1 에서 제시된 것과 같이 4 주 내에 일어난 발모의 효과는 20 와 $50 \%$ 치약을 도포한 그룹 이 minoxidil을 도포한 그룹보다 발모 효과가 뛰어난 것으로 관 찰되었다. 문헌에서 발모 효과가 있다고 알려진 $\alpha$-tocopherol acetate, l-menthol, stevioside를 혼합하고(E 그룹), 치약의 제형 과 기능을 위한 혼합성분들인 sodium fluorophosphates $0.76 \%$, calcium glycerol phosphate $0.13 \%$, sodium chloride $5 \%$, pyridoxine hydrochloride $0.03 \%$, allantoin $0.5 \%$, tranexamic acid $0.05 \%$, aminocaproic acid $0.05 \%$, sodium pyrophosphate $2 \%$, calcium carbonate $5 \%$, calcium phosphate $3.2 \%$, silica gel $2 \%$, sodium fluorophosphates $0.76 \%$, calcium glycerol phosphate $0.13 \%$, sodium chloride $5 \%$, pyridoxine hydrochloride

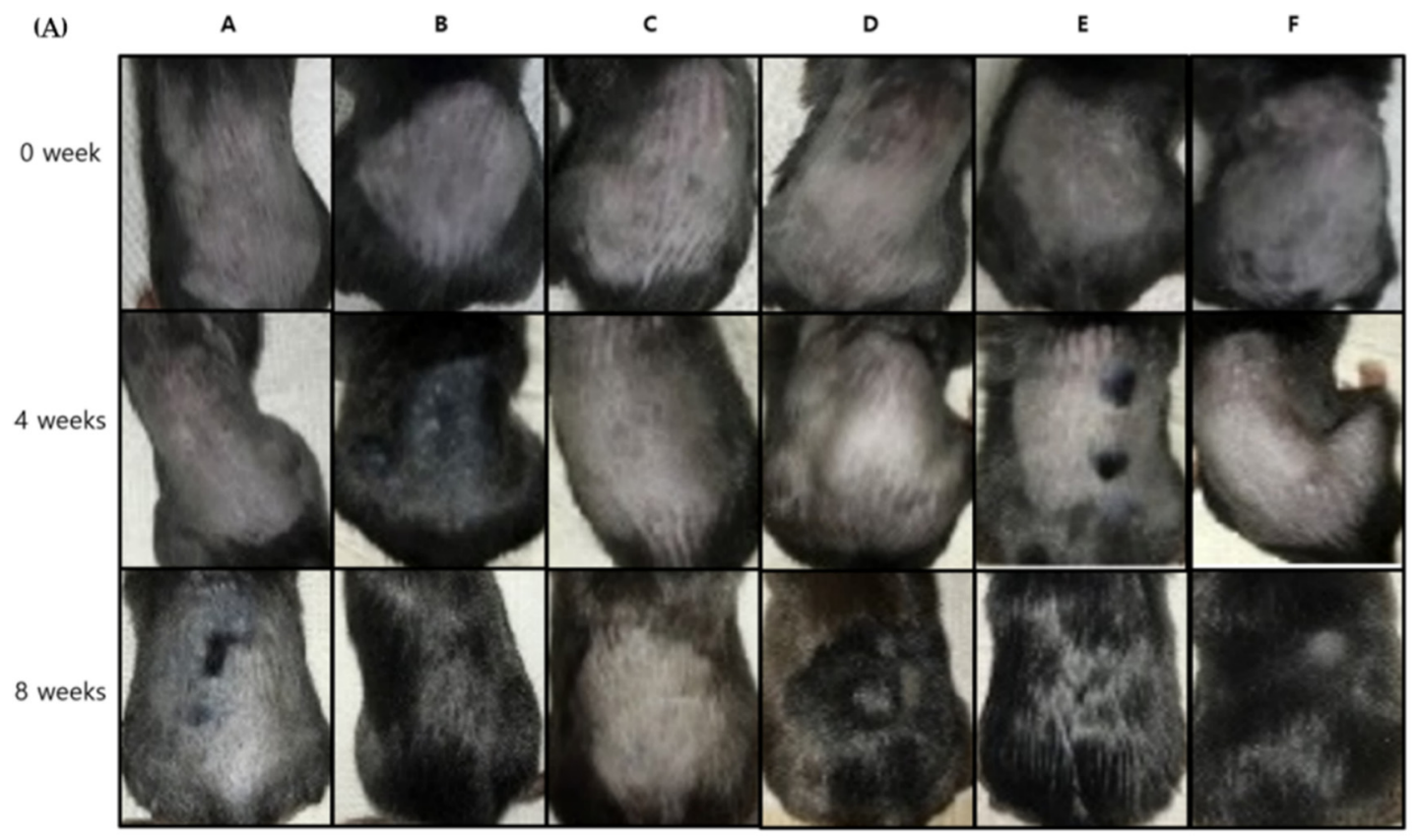

(B) Growth Area \%

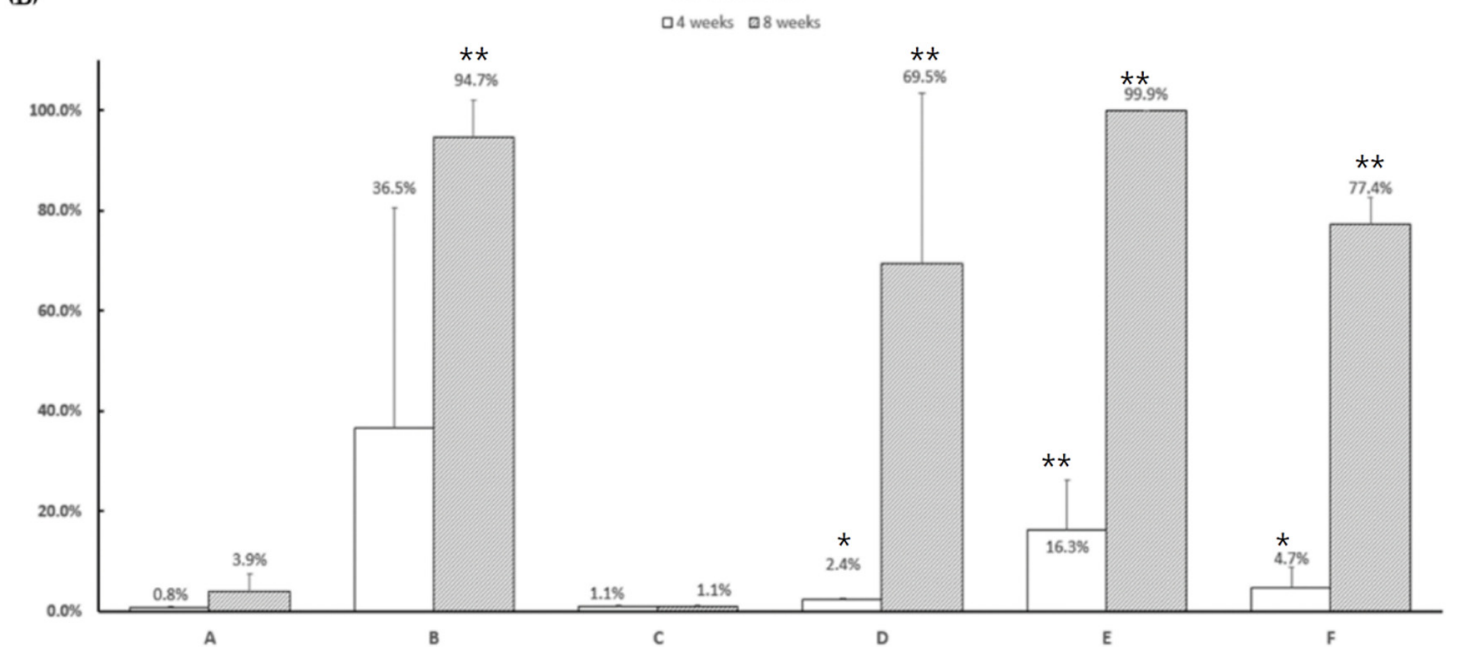

Fig. 2 Effects of toothpaste components on hair regeneration in C57BL/6 mice. (A) Time scale of the hair regrowth in C57BL/6 mice within 8 weeks after shaving. The mice were divided into 6 groups; A: CTR (treated with vehicle), B: 3\% minoxidil, C: Toothpastes mixture(TPM: sodium fluorophosphates $0.76 \%$, calcium glycerol phosphate $0.13 \%$, sodium chloride $5 \%$, pyridoxine hydrochloride $0.03 \%$, allantoin $0.5 \%$, tranexamic acid $0.05 \%$, aminocaproic acid $0.05 \%$, sodium pyrophosphate $2 \%$, calcium carbonate $5 \%$, calcium phosphate $3.2 \%$, silica gel $2 \%$ ), D: TPM $+0.2 \%$ Lmenthol $+0.5 \% \alpha$-tocopherol $+0.1 \%$ stevioside, E: $0.2 \%$ L-menthol $+0.5 \%$ tocopherol $+0.1 \%$ stevioside, F: $50 \%$ TP (toothpaste). The mice were treated every day and the back skins were photographed every week. (B) Quantitative comparison of hair growth. The hair growth area was scanned and the area was calculated using ImageJ program. The value was represented as the relative percent of the hair growth area to the shaved area. The value was represented as an average with error bar of standard deviation calculated out of individuals except the highest and lowest values in each group 
$\mathrm{SiO}_{2} \cdot 2 \mathrm{H}_{2} \mathrm{O}$

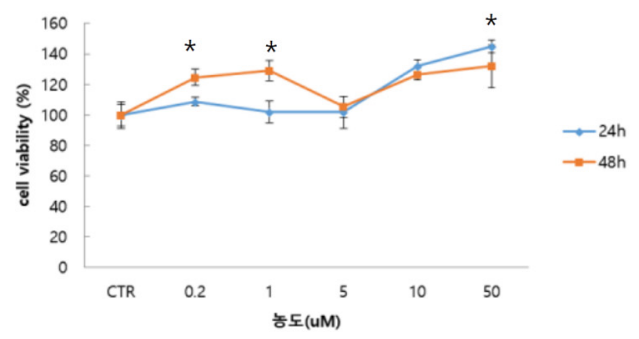

$\mathrm{CaCO}_{3}$

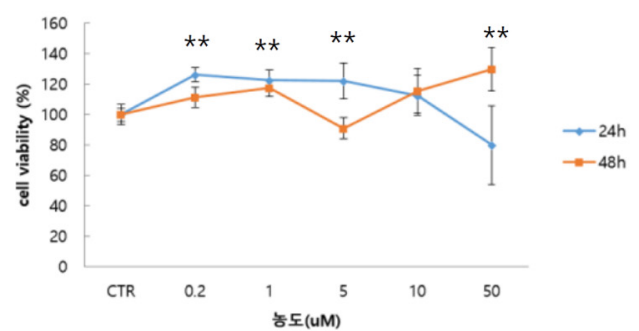

$\mathrm{NaCMC}$
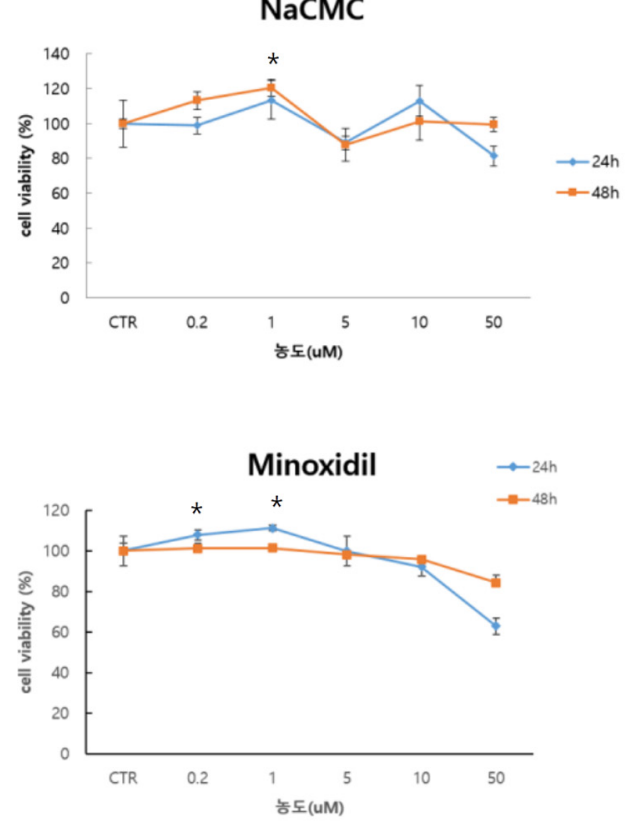

L-Menthol

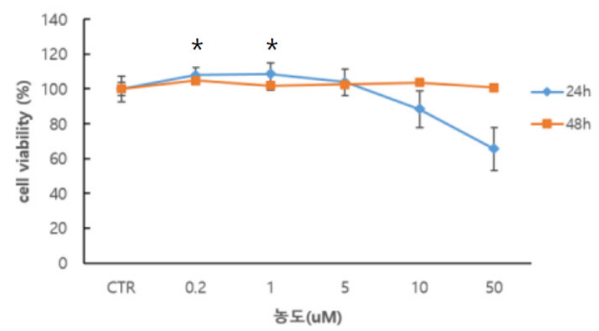

$\mathrm{Na}_{4} \mathrm{P}_{2} \mathrm{O}_{7}$

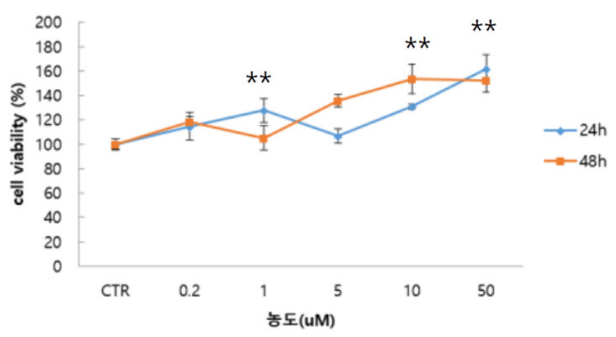

Sorbitol

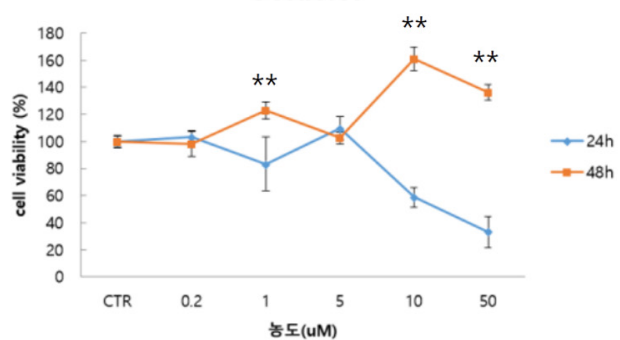

Sodium saccharin

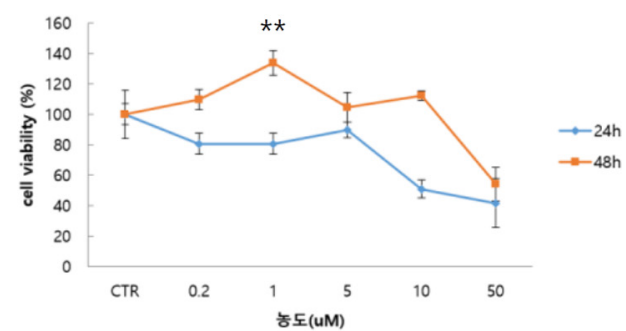

Stevioside

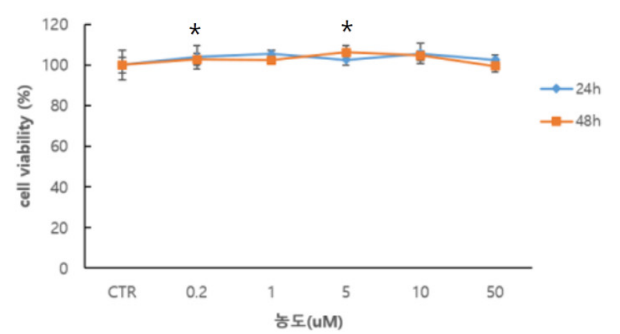

$\alpha$-Tocopherol acetate

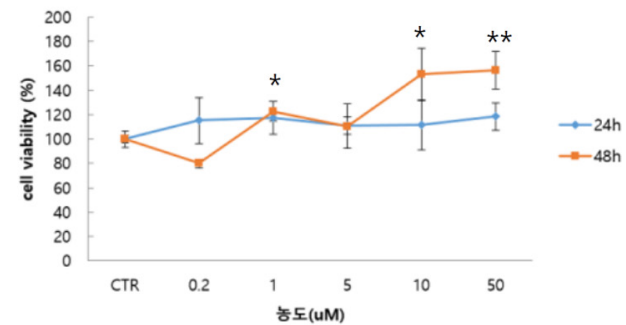

Fig. 3 Effect of toothpaste components on keratinocyte proliferation. The cells were treated with the indicated concentration $(0,0.2,1,5,10,50 \mu \mathrm{M})$ for 24 and $48 \mathrm{hrs}$. Compared with the vehicle-treated control group, the results were represented with average and standard deviation $(* p<0.05$, $* * p<0.01(\mathrm{n}=5)$ 

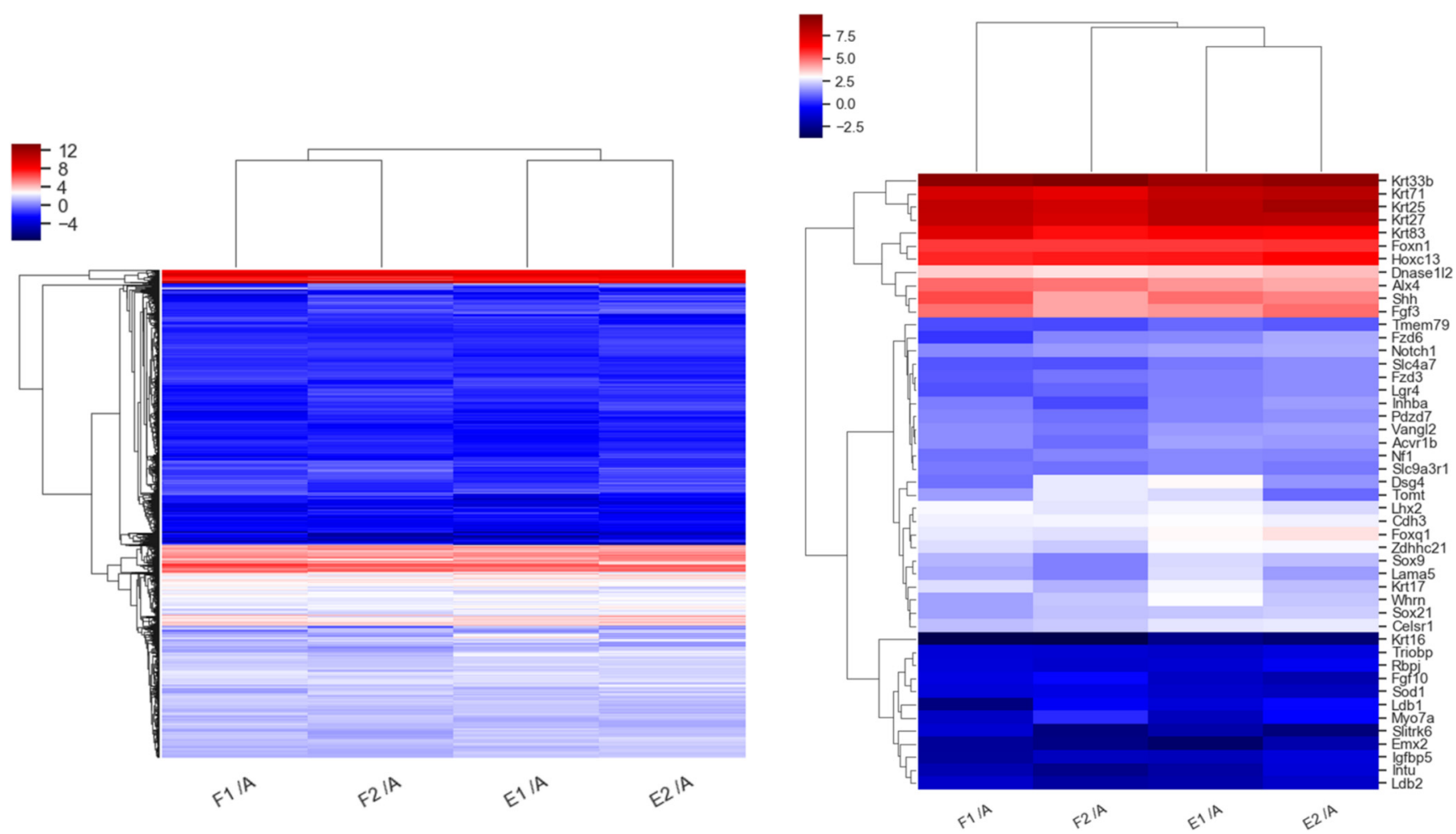

Fig. 4 Heat map of gene expression levels for each two mice (E1, E2, F1, and F2) from L-menthol+ $\alpha$-tocopherol+stevioside (E1,E2) vs CTR, and toothpaste $(\mathrm{F} 1, \mathrm{~F} 2)$ vs CTR. Significant genes were defined as those with a 3 -fold change, normalized data of 5.00, and $p$-value $<0.05$. Hierarchical clustering was performed in the functional category of hair growth

$0.03 \%$, allantoin $0.5 \%$, tranexamic phosphate $3.2 \%$, 그리고 silica gel $2 \%$ 혼합물(C 그룹)을 두개의 그룹으로 나누어 쥐의 제모 부위에 처리한 결과, $\mathrm{C}$ 그룹은 발모 효과를 보이지 않았 다(Fig. 2 group C). 그러나 C 그룹 처리 물질에 $\alpha$-tocopherol acetate와 1-menthol, stevioside 혼합액을 추가한 D group과 $\alpha$ tocopherol acetate와 1-menthol, stevioside 혼합액만을 처리한 E 그룹에서는 발모 효과가 관찰되었다(Fig. 2). 따라서 치약의 발 모 효과는 $\alpha$-tocopherol acetate와 1-menthol, stevioside 혼합액 의 효과에 기인하는 것으로 생각되었다.

\section{치약 성분이 피부 각질세포와 모유두 세포의 성장 촉진에 미치 는 역할}

치약의 성분들이 피부 각질세포 $(\mathrm{HaCaT})$ 와 모유두 세포의 성장 촉진에 미치는 역할을 알아보기 위해, MTS assay를 이용한 세 포 증식 실험을 수행하였다. 실험결과, Fig. 3에서와 같이 $\mathrm{SiO}_{2}$ $2 \mathrm{H}_{2} \mathrm{O}, \mathrm{Na}_{4} \mathrm{P}_{2} \mathrm{O}_{7}, \mathrm{CaCO}_{3}$, stevioside, sorbitol, sodium saccharin, $\alpha$-tocopherol acetate, $\mathrm{NaCMC}$ 성분이 각질세포 성장을 촉진하 는 것으로 나타났다. 또한 $\mathrm{HaCaT}$ 세포주를 이용하여 각각의 성 분을 24 시간 처리 후 $50 \%$ 이하의 생존률을 보인 sorbitol, sodium saccharin을 제외하고는 대체적으로 사멸에 영향을 주진 않는 것으로 나타났다. 한편 $\alpha$-tocopherol acetate와 $\mathrm{Na}_{4} \mathrm{P}_{2} \mathrm{O}_{7}$ 의 경우 24 시간, 48 시간 처리 경우는 모두 유의미한 증식을 보였 다. $\alpha$-tocopherol acetate $(10,50 \mu \mathrm{M})$ 를 24시간과 48시간 동안 처리한 경우에는 약 $40 \%$ 정도의 세포 증식이 관찰되었다.
Stevioside를 처리한 경우에는 $50 \mu \mathrm{M}$ 농도에서 독성을 보이지 않았지만, l-menthol과 minoxidil의 경우는 같은 농도 에서부터 는 뚜렷한 세포독성을 보였다. 또한 이 두 물질은 모두 $1 \mu \mathrm{M}$ 에서는 약간의 증식을 보여주었고, stevioside를 $1,5 \mu \mathrm{M}$ 농도 에서 처리시 약간의 증식 효과를 보였다. Sorbitol과 sodium saccharin, tocopherol acetate의 경우는 물질 처리 시간에 따른 차이가 크게 나타났다. Sorbital의 경우 $10 \mu \mathrm{M}$ 처리 24시간 후 에는 $40 \%$ 정도의 증식을 보인 반면 48 시간 후에는 $40 \%$ 의 사 멸을 일으켰고, sodium saccharin의 경우 $0.2-50 \mu \mathrm{M}$ 까지 전체적 으로 24 시간 보다는 48 시간을 처리하였을 때의 증식 효과가 조 금 더 크게 나타났다. 전체적으로 $\mathrm{SiO}_{2}-2 \mathrm{H}_{2} \mathrm{O}, \mathrm{Na}_{4} \mathrm{P}_{2} \mathrm{O}_{7}, \mathrm{CaCO}_{3}$, sorbitol, 그리고 tocopherol acetate는 고농도 $(10,50 \mu \mathrm{M})$ 를 48 시간처리하였을 때의 증식 효과가 뛰어남이 관찰되었다. 반면 $\mathrm{CaCO}_{3}, \mathrm{NaCMC}$, sodium saccharin, minoxidil, 1-menthol, stevioside는 저농도 $(1 \mu \mathrm{M})$ 에서 24 시간을 처리할 때의 증식 효 과가 뛰어난 것으로 나타났다.

\section{발모가 촉진된 조직에서의 모발 성장 관련 유전자들의 발현}

대조군(A: vehicle CTR)에서 1개체, 발모가 관찰된 D 처리군 ( $\alpha$-tocopherol acetate와 l-menthol 혼합물), 치약을 처리한 $\mathrm{E}$ 처 리군에서 각각 2 개체씩을 선택하여 마우스의 등 피부를 채취하 여 mRNA를 추출하고 transcriptome sequencing을 하였다. Quan-Seq 분석을 수행하여 처리군에서 대조군과의 발현차이가 10 배 이상 상향조절된 유전자를 약 600 개 정도 확인하였다. D 
E1

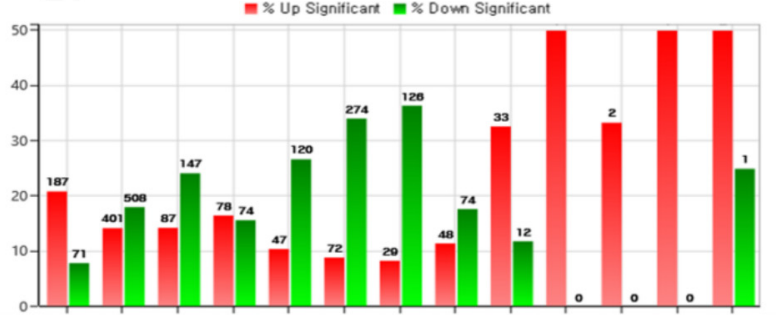

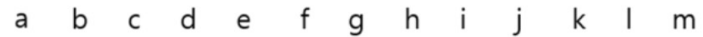

F1

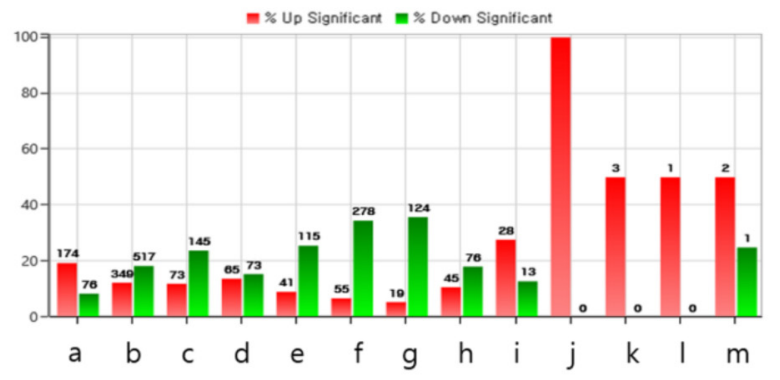

e: Extracellular matrix

$\mathrm{f}$ : Immune response

$\mathrm{g}$ : Inflammatory response h: Secretion
E2

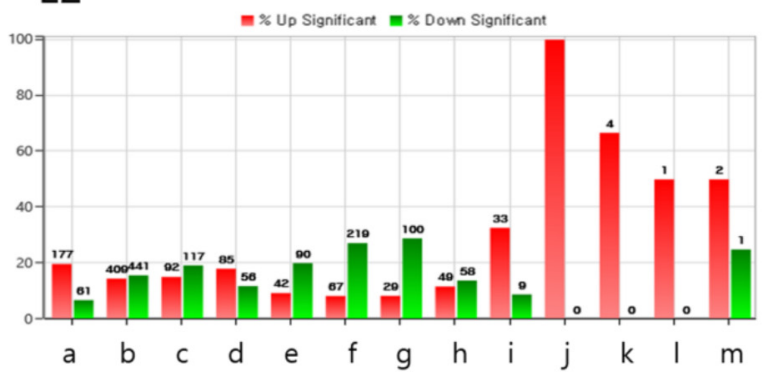

F2

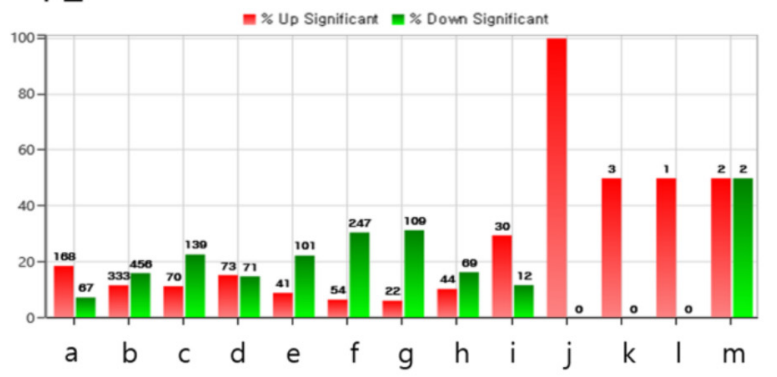

i: Hair growth

j: Positive regulation of anagen

$\mathrm{k}$ : Regulation of timing of anagen

I: Negative regulation of anagen

$\mathrm{m}$ : Positive regulation of catagen

Fig. 5 Gene category chart of E1 and E2 (L-menthol $+\alpha$-tocopherol + stevioside vs CTR) and F1 and F2 (toothpaste vs CTR)

그룹과 $\mathrm{E}$ 그룹에서 각각 2 개체씩 선택된 4 개체에서 대조군에 비교하여 조절이 변화된 유전자의 패턴을 나타낸 Fig. 4A의 유 전자 클러스터링 heatmap에서 확인할 수 있는 바와 같이 10배 이상의 발현증가를 보인 유전자 600 여개 중에서 대부분은 4 개 체 모두에서 공통적으로 발현이 상향 조절되어 나타났다. 또한 유전자 클러스터링 heatmap에서 보이는 4개체의 유전자 발현 변화의 패턴은 비슷한 것을 확인할 수 있었다(Fig. 4). 뿐만 아 니라, 조절된 유전자 기능의 카테고리(Fig. 5), 발모와 관련된 유전자 범주만을 선택하여 유전자 클러스터링 chart를 그린 Fig. 6 에서 확인할 수 있는 바와 같이, 발모와 관련된 유전자 범주 발현 변화의 패턴도 4 개체에서 매우 유사한 것을 확인할 수 있 었다. 이러한 결과를 바탕으로 볼 때, 치약의 발모 효과와 $\alpha$ tocopherol acetate와 1-menthol, stevioside 혼합물의 발모 효과 는 매우 유사한 메커니즘으로 일어나는 것으로 생각되며, 이는 개체별 차이와 관계없이 나타나는 것으로 판단되었다. 4개체 모 두에서 상향 조절된 유전자들 중에서 발모와 관련된 유전자 범 주를 뽑아서 상위부터 나열한 결과를 Table 1에 나타냈다. 모 발주기와 관련된 유전자 목록에는 $\mathrm{Krt} 33 \mathrm{~b}, \mathrm{Krt} 27, \mathrm{Krt} 25, \mathrm{Krt} 71$, Krt83, Hoxc13, Foxn1, Shh, Fgf3, Alx4, Dnase112, Foxq1, Dsg4, Whrn, Cdh3, Zdhhc21, Krt17, Lhx2, Celsr1, Lama5, Sox9, Tomt, Sox21, Notch1, Acvr1b, Vang12가 포함되어 있다. Keratin이나 keratin과 결합하는 단백질의 유전자들이 매우 높은
비율로 증가하였다. 대조군에 비교했을 때, 각 개체에서 발현이 변화한 유전자들의 gene category chart를 그린 결과는 Fig. 5 과 같다. 발모와 관련이 있다고 알려진 유전자 기능 범주인 cell cycle (total gene number: 1119), cell differentiation (3697), migration (850), extracellular matrix (505), immune response (1075), inflammatory response (490), secretion (508), hair growth (104), positive regulation of anagen (80), regulation of timing of anagen (29), negative regulation of anagen (237), and positive regulation of catagen (347)으로 기능적범 주를 한정하고 이들에 대해 유의미한 수준(fold change 2.00, normalized data 4.00, and $p$-value 0.05)으로 유전자들의 발현 이 상향 혹은 하향 조절된 것을 기반으로 작성되었다. 각 기능 별 category에서 유의성이 있게 변화한 유전자 중에서 4개체에 서 유의적으로 변화한 유전자가 차지하는 비율을 \%로 나타냈 다. $\alpha$-tocopherol acetate와 1-menthol, stevioside 혼합물을 처리 한 한 개체는 104 개 중에 45 개의 모발 성장과 관련된 유전자 가 유의미하게 조절되었고(33개: 상향조절, 12 개 하향조절), 또 한 개체는 104 개 중에 42 개의 모발 성장과 관련된 유전자가 유 의미하게 조절되어서 (33개: 상향조절, 9개 하향조절) 다른 유 전자 범주에 비해 $40 \%$ 정도가 될 정도로 기능의 반응성이 상 대적으로 높게 나타났다. 치약을 처리한 두 개체들의 경우에도 104 개 중에 41,42 개의 모발 성장과 관련된 유전자 유의미하게 
(A)

a: immune system process

b: chemotaxis

c: imflammatory response

d: innate immune response

e: immune response

$f$ : negative regulation of cell proliferation

g: response to virus

$\mathrm{h}$ : defense response to virus

i: multicellular organism development

j: cellular response to interferon-gamma

k: chemokine-mediated signaling pathway

I: keratinocyte differentiation

$\mathrm{m}$ : cellular response to interferon-beta

$\mathrm{n}$ : positive regulation of angiogenesis

o: cell adhesion

$\mathrm{p}$ : keratinization
E1

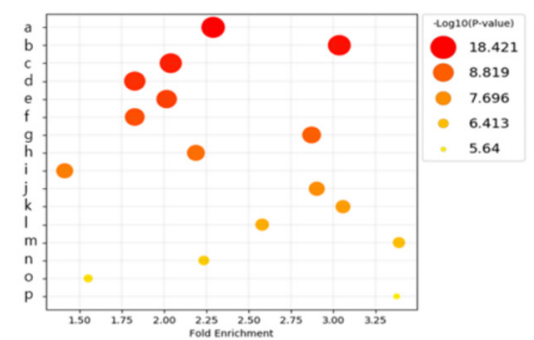

F1

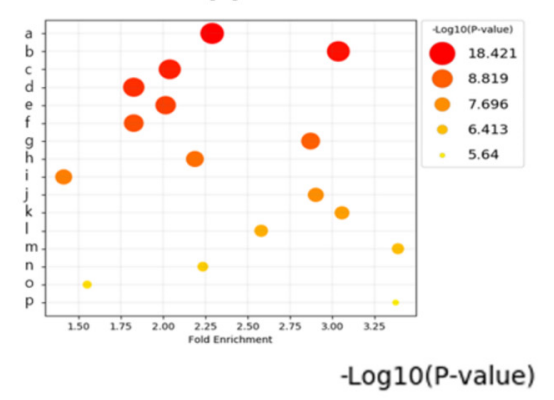

E2

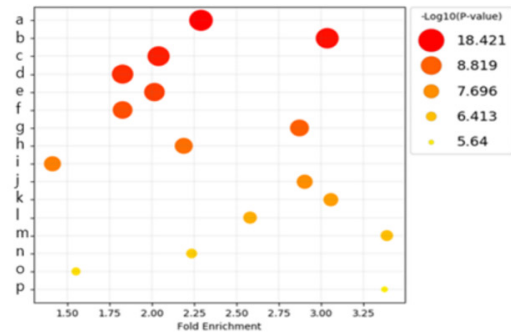

F2

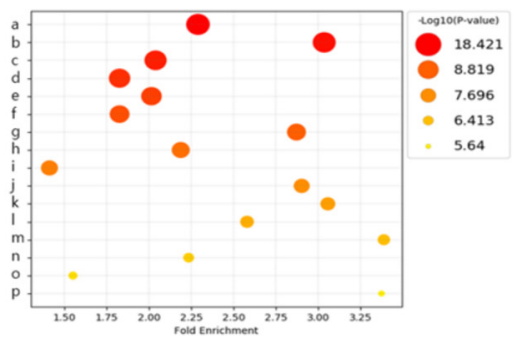

(B)

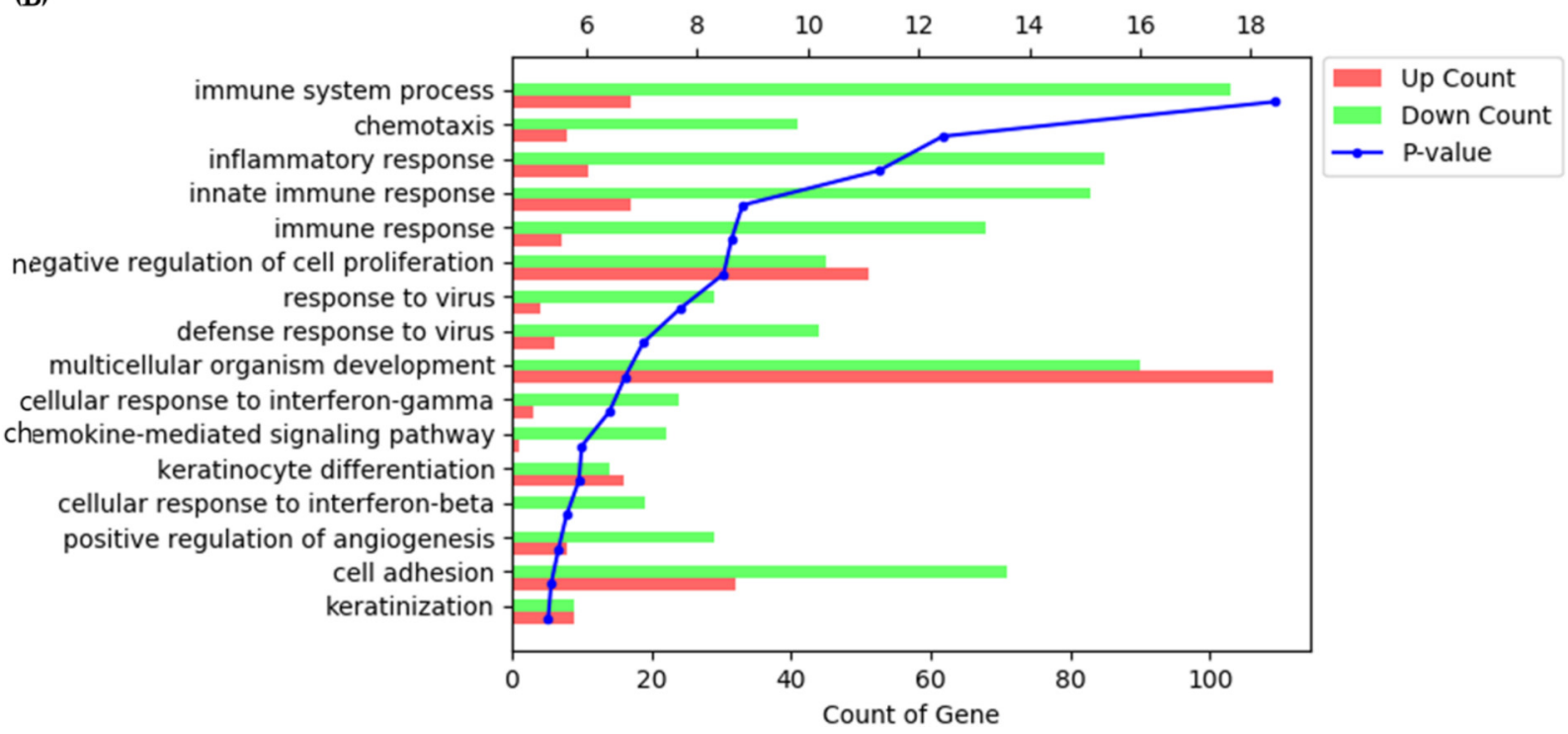

Fig. 6 (A) Functional annotation enrichment for E1, E2, F1, and F2. DAVID bioinformatics resources 6.8 analysis tool was used. (B) Genes clustering chart by selecting only the gene category related to hair growth

조절되었고(28개: 상향조절, 13 개 하향조절, 30 개: 상향조절, 12 개 하향조절) 다른 유전자 범주에 비해 각각 $40.6,41.6 \%$ 로서 기능의 반응성이 상대적으로 높게 나타났다. Hair growth category에 속하는 유전자의 경우는 유의미하게 증가하거나 $(30 \%$ 내외) 또는 감소한 유전자 $(10 \%$ 내외)의 비율이 모든 개체에서 $40 \%$ 를 넘은 결과를 보여주고 있다. 즉 치약과 $\alpha$-tocopherol acetate와 1-menthol, stevioside 혼합물이 발모 관련 유전자중의 $40 \%$ 이상에 영향을 주었다는 것을 나타낸다. 치약을 처리한 개 체들과 $\alpha$-tocopherol acetate와 1-menthol, stevioside 혼합물을 처리한 개체들은 모발 성장, 성장기(Anagen)의 양성 조절 및 세 포외 기질과 관련된 유전자의 기능적 범주를 매우 높은 비율로
유의하게 조절하였다. 각 기능 범주에서 유전자가 조절되는 패 턴은 모든 4개체에서 유사하게 관찰되었다. 확보된 transcriptome 결과를 기반으로 유전자들의 기능 분석을 위해 $\mathrm{NIH}$ 에서 제공 하는 DAVID bioinformatics resources 6.8을 사용하였다. 유전 자 ontology 분석에 따르면 $\alpha$-tocopherol acetate와 1-menthol, stevioside 혼합물을 처리하였을 때와 치약을 처리하였을 때 면 역과 관련된 pathway가 높은 순위로 영향을 받았고 각질세포분 화(Keratinocyte differentiation)나 세포의 부착과 관련된 pathway들이 영향을 많이 받는 것으로 나타났다(Fig. 6). 4개체 의 ontology 분석 결과 조절된 상위 pathway는 모두 동일하게 나타나서, 같은 유전자 조절이 보임을 확인할 수 있었다(Fig. 
Table 1 Top 26 most up-regulated hair growth related genes in the 4 entities (E1 vs, CTR, E2 vs. CTR, F1 vs. CTR, F2 Vs. CTR) E1, E2 from mixture treatment group. F1, F2 from toothpaste treatment group

\begin{tabular}{|c|c|c|c|c|c|}
\hline ID & Gene Symbol & $\mathrm{E} 1 / \mathrm{A}$ & $\mathrm{E} 2 / \mathrm{A}$ & F1/A & F2/A \\
\hline 3686 & Krt33b & 531.786 & 670.795 & 703.853 & 900.793 \\
\hline 3641 & Krt27 & 319.026 & 307.145 & 255.717 & 182.870 \\
\hline 3639 & Krt25 & 315.924 & 448.680 & 272.228 & 205.557 \\
\hline 7399 & $\mathrm{Kt} 71$ & 261.071 & 310.654 & 184.072 & 133.465 \\
\hline 7382 & Krt83 & 93.447 & 84.108 & 149.475 & 76.367 \\
\hline 7438 & Hoxc13 & 70.267 & 86.235 & 60.887 & 68.330 \\
\hline 3283 & Foxn1 & 51.097 & 55.008 & 49.897 & 50.040 \\
\hline 15279 & Shh & 31.521 & 26.336 & 43.097 & 18.466 \\
\hline 19818 & Fgf3 & 21.967 & 31.392 & 30.616 & 18.429 \\
\hline 11623 & Alx4 & 21.242 & 17.699 & 32.830 & 28.717 \\
\hline 8439 & Dnase112 & 12.250 & 14.721 & 12.999 & 10.767 \\
\hline 5140 & Foxq1 & 8.713 & 10.601 & 6.737 & 6.291 \\
\hline 9414 & Dsg4 & 8.689 & 3.032 & 2.222 & 6.690 \\
\hline 14110 & Whrn & 8.038 & 4.803 & 3.437 & 4.710 \\
\hline 20698 & Cdh3 & 8.004 & 7.192 & 7.166 & 7.345 \\
\hline 14151 & Zdhhc21 & 7.915 & 7.857 & 6.037 & 5.051 \\
\hline 3698 & Krt17 & 7.379 & 4.509 & 5.985 & 3.915 \\
\hline 11095 & Lhx2 & 7.353 & 5.668 & 7.600 & 6.536 \\
\hline 7181 & Celsr1 & 6.402 & 6.644 & 4.430 & 4.964 \\
\hline 12547 & Lama5 & 6.013 & 3.308 & 3.635 & 2.521 \\
\hline 3913 & Sox 9 & 5.840 & 4.435 & 4.072 & 2.546 \\
\hline 19061 & Tomt & 5.795 & 2.020 & 3.315 & 6.647 \\
\hline 6565 & Sox 21 & 4.874 & 5.123 & 3.395 & 4.568 \\
\hline 10873 & Notch1 & 3.575 & 3.816 & 2.809 & 3.236 \\
\hline 7372 & Acvr1b & 3.407 & 3.175 & 2.911 & 2.133 \\
\hline 1074 & Vang12 & 3.198 & 3.424 & 2.818 & 2.370 \\
\hline
\end{tabular}

6A). 발모효과를 보인 쥐의 조직에서 변화를 보인 관련 유전자 들의 상관 관계를 분석하기 위하여 http://string-db.org/에서 multiple protein의 network를 그린 결과는 Fig. 7과 같다. 본 연구에서는 C57BL/6 마우스를 이용한 in vivo 실험에서 4주에 서 8 주간의 치약의 도포가 발모효과를 보이는 것을 확인하였다. 치약의 성분으로 알려진 것 들 중에서 $\alpha$-tocopherol acetate와 1menthol, stevioside 혼합물을 도포하였을 때 C57BL/6 마우스에 서 모발성장 촉진효과가 보임을 확인하였다. 4주후, 8 주후의 발 모 면적 부위를 비교하여 확인하였다. 또한, 대조군으로 사용된 vehicle 처리군에서는 제모 후 4-5주차 이후부터 제모부위에 검 은색 반점이 나타나지만, 양성 대조군으로 사용된 $3 \%$ 의 minoxidil 혹은 치약이나 $\alpha$-tocopherol acetate와 l-menthol, stevioside 혼합물을 처리한 군에서는 발모 후 3주차 때 제모부 위가 검은색으로 되는 것을 관찰할 수 있어서 발모 촉진을 가 져오는 효과를 확인할 수 있었다. 이는 치약에 의한 발모촉진 효과와 그와 관련된 활성성분을 조사한 첫 연구이다. 모간은 진 피유두(DP)와 모간을 둘러싸고 있는 모질에 있는 표피 각질형 성세포와 구근에 있는 진피유두 세포로 나눌 수 있다. 팽대부 와 그 안에 포함된 진피유두(DP) 세포는 모낭 모발 성장(성장 기) 및 재생(휴지기에서 성장기로 전환)에 중요한 역할을 한다
[9]. 진피유두 세포는 주변 상피 세포와 상호 작용하여 성장기 (Anagen phase)에 구근 상피의 증식 및 분화에 의해 모간 연장 을 초래한다[10]. 적절한 상피-진피유두간의 소통은 모낭의 성 장과 순환에 매우 중요하다[11]. 특별히 모유두(DP)는 각질세포 (Keratinocytes)와 인접한 곳에 놓여있어 모간 내에서 keratinocyte 의 증식과 분화를 조절하는데 결정적인 인슐린 유사 성장 인자 (IGF-1), 간세포 성장 인자 및 혈관 내피 성장인자 등을 포함한 신호를 생산한다[12,13]. 그러므로 진피유두세포들(DPCs)이 모 발의 성장에 있어 사령탑이라고 제안된다[13,14]. 진피유두세포 (DP)의 개수가 쥐의 모낭에서 모간의 크기와 형태에 관련되어 있다는 사실은 이미 알려져 있다[15]. 이에 더불어 진피유두세 포들의 수는 사람의 모발주기의 성장기동안 증가한다[16]. 발모 촉진의 약으로써 사용될 수 있는 새로운 화합물의 잠재력을 평 가하기 위해서는 일반적으로 그 물질이 keratinocyte나 HDP세포 증식을 촉진할 수 있는지 없는지를 조사한다. 따라서 본 논문 은 치약 성분들 일부를 이용하여 $\mathrm{HaCaT}$ 세포의 증식 여부를 조사하였는데, $\alpha$-tocopherol acetate 처리 시 세포 증식 효과를 보였고, 1-menthol과 stevioside 처리에 의한 유의성 있는 증가 는 나타나지 않았다. L-menthol과 minoxidil은 일정 농도 이상 처리할 경우 세포독성을 보이는 것으로 관찰되었다. 또한 $\mathrm{SiO}_{2}$, 


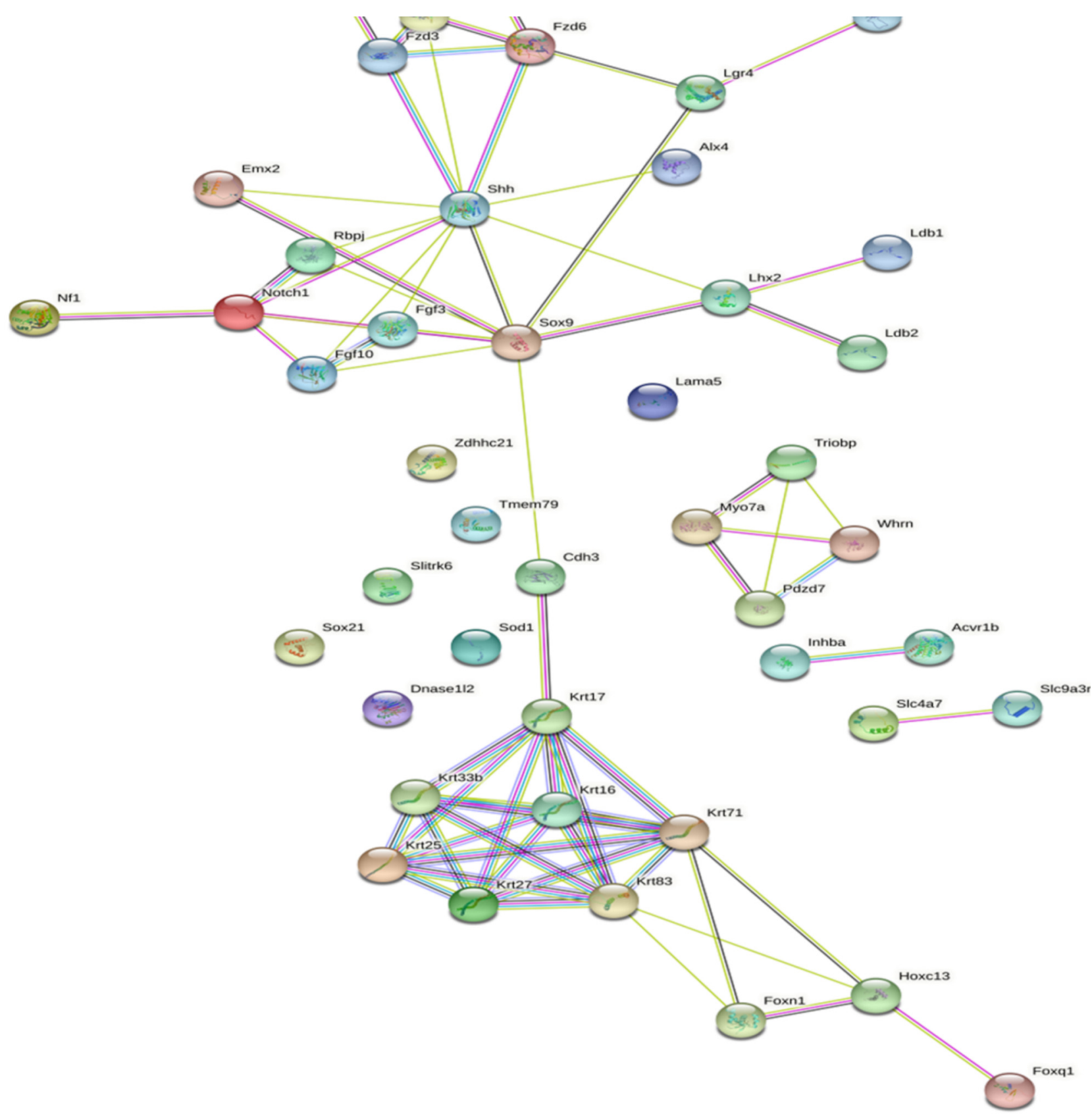

Fig. 7 String network of genes associated with toothpaste vs CTR (F1 mouse)

sodium pyrophosphate, sorbitol 등의 성분도 일정 농도 이하에 서 세포 증식을 촉진시키는 것으로 보이나, in vivo에서 발모 촉진은 보고 된 적이 없으므로 keratinocyte 증식효과를 측정하 여 발모 촉진 효과 물질을 확인하는 것에는 한계가 있는 것으 로 생각된다. Minoxidil은 keratinocyte에서 $0.2 \mu \mathrm{M}$ 과 $10 \mu \mathrm{M}$ 사이에서 48 시간 처리 시 세포증식효과를 보였고 $50 \mu \mathrm{M}$ 로 처 리했을 때 세포독성이 관찰되었는데 $50 \mu \mathrm{M}$ 은 $0.001 \%$ 로 생리 학적으로 $3-5 \%$ 의 농도에 비해 더 낮은 농도이다. 한편, 본 연 구의 전사체(transcriptome) 기반 계층적 clustering 결과, 치약 처리군 대 대조군에서 얻은 상위 200 개의 상향 조절된 유전자
들과 $\alpha$-tocopherol acetate와 1-menthol, stevioside 혼합물 처리 군 대 대조군간을 비교했을 때 큰 차이를 보인 것들 중 상향 조절된 것들은 매우 큰 유사성을 보였으며 해당 유전자들은 모 발의 성장과 관련된 것들로 나타났다. DAVID 유전자 ontology biological process를 사용하여 수행한 KEGG 경로 분석은 치약 처리한 군에서 면역 관련 신호 전달, 염증 관련 신호전달, 각질 세포 분화 등과 관련된 신호전달 경로 등이 관여하고 있음을 보여주었다. 발모효과를 보인 쥐의 조직에서 증가를 보인 발모 관련 유전자들의 상관 관계를 그린 string database 결과에서는 436개의 node, 평균 node degree 6.5 , 평균 local clustering 
coefficient 0.483 값을 보이면서, 유의미한 상호작용들을 보여주 었다. 19 개의 keratin 섬유 단백질들, 46 개의 중간 섬유 단백질, 5 개의 melanosome 막 단백질, 11 개의 DNA 상호작용 단백질 등이 연관되어 있었다. 특히 Sox9등의 전사조절인자 단백질은 다양한 keratin 단백질의 전사 조절에 관여하는데, 치약에 의한 발모에 이 기능의 단백질들이 연관되어 조절되고 있음을 확인 하였다.

\section{초 록}

예전부터 치약이 모발성장을 촉진시킬 수 있는 잠재력을 갖고 있다고 제안되어 왔지만 발모효과에 대한 과학적 검증과 치약 내 주요 활성성분에 대한 연구는 보고된 바가 없다. 따라서 본 연구에서는 치약을 이용하여 피부 각질세포의 성장 및 C57BL/ 6 마우스의 제모된 등쪽 피부에 국소적으로 적용하여 모발의 성 장 촉진 여부를 평가하였다. 본 연구 결과 치약의 구성 성분으 로서 문헌에서 발모 효과가 있다고 알려진 $\alpha$-tocopherol acetate 와 1-menthol, stevioside 혼합액과, 이들을 제외한 치약 조성 성 분들의 혼합액을 각각 두 그룹의 $\mathrm{C} 57 \mathrm{BL} / 6$ 마우스의 제모된 피 부에 국소적으로 적용한 경우, 치약 성분의 혼합액은 발모효과 를 보이지 않았고, $\alpha$-tocopherol acetate과 1-menthol, stevioside 혼합액이 포함되었을 경우에는 마우스에서 발모 효과가 나타났 다. 따라서, 치약을 구성하는 보조성분들인 $\alpha$-tocopherol acetate 과 1-menthol, stevioside 혼합물은 in vivo에서의 모발성장에 있 어 잠재력을 갖고 있음을 확인하였다. 또한 치약을 처리한 그 룹의 마우스와 발모 유효 성분으로 추정되는 $\alpha$-tocopherol acetate과 l-menthol, stevioside를 혼합 처리한 그룹의 마우스, 그리고 대조군의 마우스의 등쪽 표피를 취하여 전사체 분석을 진행한 결과 대조군에 비해서 각각의 처리군에서 유의적으로 발 현된 유전자 패턴은 매우 유사함을 보였다. 또한 기능유전체적 분석을 하였을 때, 두 그룹에서 공통적으로 발모 조절 관련 기 능의 유전자들이 매우 큰 비율의 변화를 보였다. 두 그룹에서 발현이 변화한 발모관련 유전자들로는 케라틴과 케라틴 관련 단 백질, forkhead box, sonic hedgehog 등이 관찰되었다. 따라서, 치약의 발모 효과는 $\alpha$-tocopherol acetate과 l-menthol, stevioside 혼합물의 효과에 기인하는 것으로 생각된다.

Keywords 멘솔 · 발모 · 스테비오사이드 · 치약 · 토코페롤아 세테이트 · C57BL/6

\section{Abbreviation}

Dermal Papilla (DP): 진피유두세포

Human Dermal Papilla (HDP): 사람진피유두세포

Hair Follicle (HF): 모낭세포

감사의 글 본 논문은 과학기술정보통신부 개인기초연구(과기정통부) (R\&D)2019R1F1A1043896 과 중소벤처기업부 지역특화산업육성+(R\&D) S2913492의 지원을 받아 수행되었습니다.

\section{References}

1. Hosking AM, Juhasz M, Atanaskova Mesinkovska N (2019) Complementary and Alternative Treatments for Alopecia: A Comprehensive Review. Skin Appendage Disord 5: 72-89. doi:10.1159/ 000492035

2. Beoy LA, Woei WJ, Hay YK (2010) Effects of tocotrienol supplementation on hair growth in human volunteers. Trop Life Sci Res 21: 91-99

3. Oh JY, Park MA, Kim YC (2014) Peppermint Oil Promotes Hair Growth without Toxic Signs. Toxicol Res 30: 297-304. doi:10.5487/TR.2014. 30.4.297

4. Goralczyk (RB C, Graeub, Remo (Basel, CH), Mayne0mechan, Annis Olivia (Basel, $\mathrm{CH}$ ), Mohajeri, Hasan (Basel, CH), Piussi, Jenny (Basel, $\mathrm{CH}$ ), Rieger, Henry (Basel, $\mathrm{CH}$ ), inventor; DSM NUTRITIONAL PRODUCTS LTD. (Kaiseraugst, NL), assignee (2013) TOPICAL USE OF STEVIOL OR DERIVATIVES IN HAIR CARE, United States

5. Muller-Rover S, Handjiski B, van der Veen C, Eichmuller S, Foitzik K, McKay IA, Stenn KS, Paus R (2001) A comprehensive guide for the accurate classification of murine hair follicles in distinct hair cycle stages. J Invest Dermatol 117: 3-15. doi:10.1046/j.0022-202x.2001. 01377.x

6. Langmead B, Salzberg SL (2012) Fast gapped-read alignment with Bowtie 2. Nat Methods 9: 357-359. doi:10.1038/nmeth.1923

7. Quinlan AR, Hall IM (2010) BEDTools: a flexible suite of utilities for comparing genomic features. Bioinformatics 26: 841-842. doi:10.1093/ bioinformatics/btq033

8. Gentleman RC, Carey VJ, Bates DM, Bolstad B, Dettling M, Dudoit S, Ellis B, Gautier L, Ge Y, Gentry J, Hornik K, Hothorn T, Huber W, Iacus S, Irizarry R, Leisch F, Li C, Maechler M, Rossini AJ, Sawitzki G, Smith C, Smyth G, Tierney L, Yang JY, Zhang J (2004) Bioconductor: open software development for computational biology and bioinformatics. Genome Biol 5: R80. doi:10.1186/gb-2004-5-10-r80

9. Yang CC, Cotsarelis G (2010) Review of hair follicle dermal cells. J Dermatol Sci 57: 2-11. doi:10.1016/j.jdermsci.2009.11.005

10. Ohn J, Kim KH, Kwon O (2019) Evaluating hair growth promoting effects of candidate substance: A review of research methods. J Dermatol Sci 93: 144-149. doi:10.1016/j.jdermsci.2019.02.004

11. Sennett R, Rendl M (2012) Mesenchymal-epithelial interactions during hair follicle morphogenesis and cycling. Semin Cell Dev Biol 23: 917927. doi:10.1016/j.semcdb.2012.08.011

12. Stenn KS, Paus R (2001) Controls of hair follicle cycling. Physiol Rev 81: 449-494. doi:10.1152/physrev.2001.81.1.449

13. Su YS, Fan ZX, Xiao SE, Lin BJ, Miao Y, Hu ZQ, Liu H (2017) Icariin promotes mouse hair follicle growth by increasing insulin-like growth factor 1 expression in dermal papillary cells. Clin Exp Dermatol 42: 287-294. doi:10.1111/ced.13043

14. Paus R, Foitzik K (2004) In search of the "hair cycle clock": a guided tour. Differentiation 72: 489-511. doi:10.1111/j.1432-0436.2004.07209004.x

15. Chi W, Wu E, Morgan BA (2013) Dermal papilla cell number specifies hair size, shape and cycling and its reduction causes follicular decline. Development 140: 1676-1683. doi:10.1242/dev.090662

16. Elliott K, Stephenson TJ, Messenger AG (1999) Differences in hair follicle dermal papilla volume are due to extracellular matrix volume and cell number: implications for the control of hair follicle size and androgen responses. J Invest Dermatol 113: 873-877. doi:10.1046/ j.1523-1747.1999.00797.x 